PROBLEMS

OF EDUCATION

IN THE $21^{\text {st }}$ CENTURY

Vol. 77, No. 1, 2019

244

\title{
EVALUATION OF SELF-EFFICACY IN PROSPECTIVE PRIMARY SCHOOL TEACHERS IN THE CONTEXT OF MATHEMATICS TEACHING
}

\author{
Radka Dofková \\ Palacký University Olomouc, Czech Republic \\ E-mail: radka.dofkova@upol.cz
}

\begin{abstract}
Positive perception of one's efficacy among teachers is a crucial factor affecting the quality of the teaching process. Many research studies suggest that self-efficacy in prospective teachers can be acted upon. It is therefore very important to focus on the preparation of prospective teachers in the context of undergraduate courses. The objective of the research study was to identify the level of self-efficacy among primary pre-service teachers of mathematics. The research sample comprised 77 students of primary teacher training enrolled in two study programmes aged between 21 and 26 years. The results were obtained by means of a newly developed tool Self-Efficacy of Prospective Teachers in Mathematics (SEPTM), which contained 37 items. The results of the research suggest that prospective teachers assess their readiness for future mathematics teaching in a positive way and trust their own abilities to use various teaching methods and procedures.
\end{abstract}

Keywords: primary math education, prospective math teacher, teacher's beliefs, teacher's self-efficacy

\section{Introduction}

The recent years have witnessed a growing interest in teacher self-efficacy. Skaalvik and Skaalvik (2007) summarized that teacher self-efficacy has been shown to predict teachers' goals and aspirations (Muijs \& Reynolds, 2002), teachers' attitudes toward innovation and change (Fuchs, Fuchs, \& Bishop, 1992; Guskey, 1988), teachers' tendency to refer difficult pupils to special education (Meijer \& Foster, 1988; Soodak \& Podell, 1993), teachers' use of teaching strategies (Allinder, 1994), and the likelihood that teachers will stay in the teaching profession (Burley, Hall, Villeme, \& Brockmeier, 1991; Glickman \& Tamashiro, 1982).

The concept of self-efficacy has been based on the theoretical framework of the social cognitive theory (Bandura, 1977). Bandura (2002) suggested the following definition of selfefficacy: "Perceived self-efficacy is defined as people's judgments of their capabilities to organize and execute courses of action required to attain designated types of performance" ( $\mathrm{p}$. 94). From this perspective, it is the perception of one's efficacy that affects the setting of goals and is determined by one's conduct and external conditions (Schunk \& Meece, 2006). The degree of self-efficacy determines how the individual perceives environmental opportunities and obstacles (Bandura, 2006a), affects the selection of activity and effort invested in the activity, and also the time for which the individual is able to overcome the obstacles (Pajares, 1997). 
Teacher's self-efficacy is the belief in their potentialities to organize and carry out activities required to achieve the set educational goals. Therefore, it is "the belief or conviction that the teacher can influence the learner's performance” (Guskey \& Passaro, 1994, p. 628). Generally, the important aspects include the degree to which the teacher is able to affect the students, teaching quality, teacher's perception of one's responsibility for the students' development and performance, perception of one's methods of problem solving in class, etc. Self-efficacy is a motivational potential of the teacher and determines the amount of energy that the teacher is able to invest in his/her work, teacher's persistence in resolving educational issues, and teacher's effort to resolve problems (Gavora, 2010).

Teachers usually think of their occupation as a mission. Being aware of this mission may be influenced by their life orientation and especially beliefs that change and develop throughout their career. At a particular stage of the development of the teacher's attitude to oneself, an important role is played by the university environment - including physical and environmental factors, social characteristics of different study groups, teachers' behaviour, and normative requirements of study programmes. According to Ashton (1984), teacher education programmes should utilize teacher efficacy belief instruments to assist pre-service teachers in clarifying their beliefs and "...develop a well-organized conception of how these beliefs would be represented in behaviour" (p. 29). Therefore, teacher education programmes need to provide more than science content for prospective elementary teachers and need to be aimed at field experiences (Enochs \& Riggs, 1990). Also, according to Bandura (1981) self-efficacy can be enhanced through modelling and successful mastery experiences, i.e. techniques used mostly in practical teaching training.

Regarding the fact that teachers' self-efficacy beliefs influence their overall functioning in the teaching process, the purpose of the analysis is to achieve a better understanding of the role that teachers have in the teaching process (Dofková \& Kvintová, 2017). Research studies on self-efficacy in prospective teachers have been performed for over 40 years and a large number of measurement tools have been designed. For instance, Bandura (1997, 2006b) formulated basic recommendations for the development of research instruments aimed at teacher self-efficacy:

- Regarding the fact that self-efficacy is related to personal perceived efficacy, the items of the questionnaire should include verbs such as "I can" or "I am able to" to make clear that these items indicate personal expectations of one's abilities.

- The items of the questionnaire should be formulated in the first person singular ("I") because the objective is to assess teachers' subjective beliefs about their own abilities.

- Each item of the questionnaire should contain a barrier. Bandura (1997) emphasises that if there are no barriers to overcome and the activity is simple, the respondents tend to indicate a similar degree of self-efficacy.

The problem with research on prospective teacher self-efficacy is that the construct has been conceptualized and measured differently by different researchers. It has proved necessary to develop a measurement tool that would match the specific Czech environment and examine self-efficacy in prospective teachers. Therefore, a new tool has been developed called the SelfEfficacy of Prospective Teachers in Mathematics (SEPTM). This instrument was used in the research. One aim of the research was to introduce a scale of teacher self-efficacy built on an analysis of prospective teachers' beliefs in mathematics. The other aim was to verify whether teacher self-efficacy could be distinguished by field of study.

\begin{tabular}{|l} 
PROBLEMS \\
OF EDUCATION \\
IN THE 21 $1^{\text {st }}$ CENTURY \\
Vol. 77, No. 1, 2019 \\
\hline 245
\end{tabular} 
Radka DOFKOVÁ. Evaluation of self-efficacy in prospective primary school teachers in the context of mathematics teaching

$\begin{array}{r}\text { PROBLEMS } \\ \text { OF EDUCATION } \\ \text { IN THE 21 } 1^{\text {st }} \text { CENTURY } \\ \text { Vol. 77, No. 1, 2019 } \\ \hline 246\end{array}$

\section{Research Focus}

In each area, the questionnaire items were evaluated on two basic levels - overall results and results by field of study. Regarding these levels, the following research questions were formulated:

(RQ1) What is the overall evaluation of self-efficacy among the respondents in the areas of research?

(RQ2) Are there any differences in prospective teachers' evaluation by study groups?

\section{Research Methodology}

\section{General Background and Sample}

The research was conducted in the winter semester of the 2017/2018 academic year at the Faculty of Education, Palacký University Olomouc in the Czech Republic. The SEPTM instrument was applied among prospective mathematics teachers enrolled in mathematical courses. The pilot research involved a total of 77 students divided into two groups.

The first group comprised 49 elementary school teacher programme (ESTP) participants (48 female and 1 male) aged 22 to 26 years (mean age $=23.06 ; S D=.682$ ) in grade three. The second group comprised 28 elementary school and special education teacher programme $($ ESSETP) participants (all female) aged 21 to 23 years (mean age $=22$ year, $S D=.463$ ) in grade four.

Both groups took a course in mathematical didactics with some differences according to the focus of their study. The content of the courses was very similar to primary school mathematical didactics and focused on the development of mathematics teaching with an emphasis on students' motivation to learn, creativity, educational constructivism, researchoriented teaching, etc. The ESETP course also focuses on students' special needs in mathematics because the graduates should have educational competences of a fully qualified teacher and specialized teacher.

\section{Instrument and Procedures}

The SEPTM scale retained the 5-point Likert scale (Strongly agree - Agree - Neither agree, nor disagree - Disagree - Strongly disagree). The final version of the SEPTM scale had a total of 37 items. The process of its construction has previously been described in detail and published (Dofková \& Kvintová, 2018). The intended structure of the questionnaire focused on three main areas - evaluation of one's capabilities, concerns about the quality of one's readiness, and teacher's responsibility for students' performance. Cronbach's alpha was calculated, and the reliability coefficient was .74. For the purposes of examining content validity, the opinions of experts were taken into account. A factor analysis was performed to elicit the fundamental dimensions of the survey.

The largest area was the evaluation of one's capabilities. It contained a total of 19 items focusing on prospective teachers' readiness for extracurricular activities, students' questions, evaluation of one's capabilities in the area of mathematics teaching, and development of a positive attitude to mathematics.

The second area focusing on concerns about the quality of one's readiness comprised nine negatively formulated items, also arranged in three areas: concerns about teaching mathematics, weaknesses concerning one's readiness, and concerns about classroom observations in mathematics lessons. 
The third area of teachers' responsibility for students' performance included a total of nine items in two areas - teacher's influence on the effectiveness of mathematics teaching and the qualities of a good teacher.

\section{Data Analysis}

Regarding the formulated research questions, the text below includes the results of the first research area relating to the evaluation of one's capabilities. In the graphical representation and statistical processing, the contingency table was reduced by combining the responses Strongly agree and Agree, which were interpreted as "positive responses", and Disagree and Strongly disagree, which were interpreted as "negative responses". The Neither agree, nor disagree item was interpreted as a "neutral response".

For each item of the questionnaire the following hypotheses were formulated:

$\mathrm{H}_{0}$ : The response to the item does not differ by respondent group.

$\mathrm{H}_{A}$ : The response to the item differs by respondent group.

The data were processed by means of the Pearson's chi-squared test and Fisher's combinatorial test. Using these tests, the $p$-value was determined and compared with the level of significance of $\alpha=.05$. The research data were processed using a free statistical programme R (R Core Team, 2013), Statistica programme, and MS Excel.

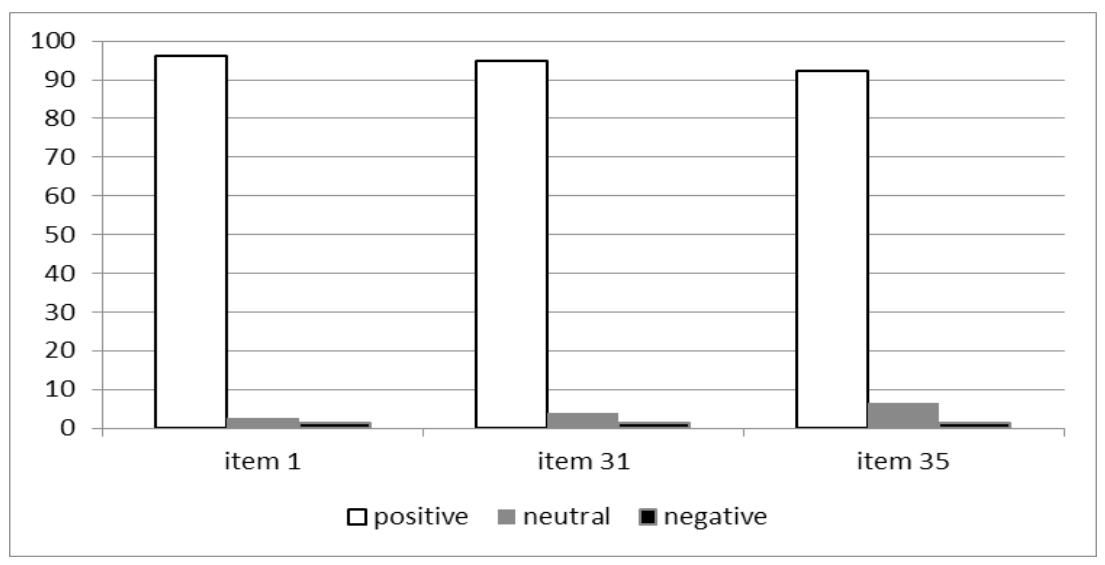

\section{Figure 1: Evaluation of one's capabilities - items with the most positive evaluation.}

\section{Research Results}

\section{Overall Results}

The overall results reflecting the evaluation of the respondents' own capabilities are summarized in Figure 1, which suggests that the item with the most positive evaluation (always exceeding $90 \%$ of responses) was the respondents' constant effort to search for better ways of teaching mathematics (Item 1). The second item was building the students' trust in their own capabilities (Item 31); the third item was exerting a stimulating effect on the students (Item 35). 
PROBLEMS

OF EDUCATION

IN THE $21^{\text {st }}$ CENTURY

Vol. 77 , No. 1,2019

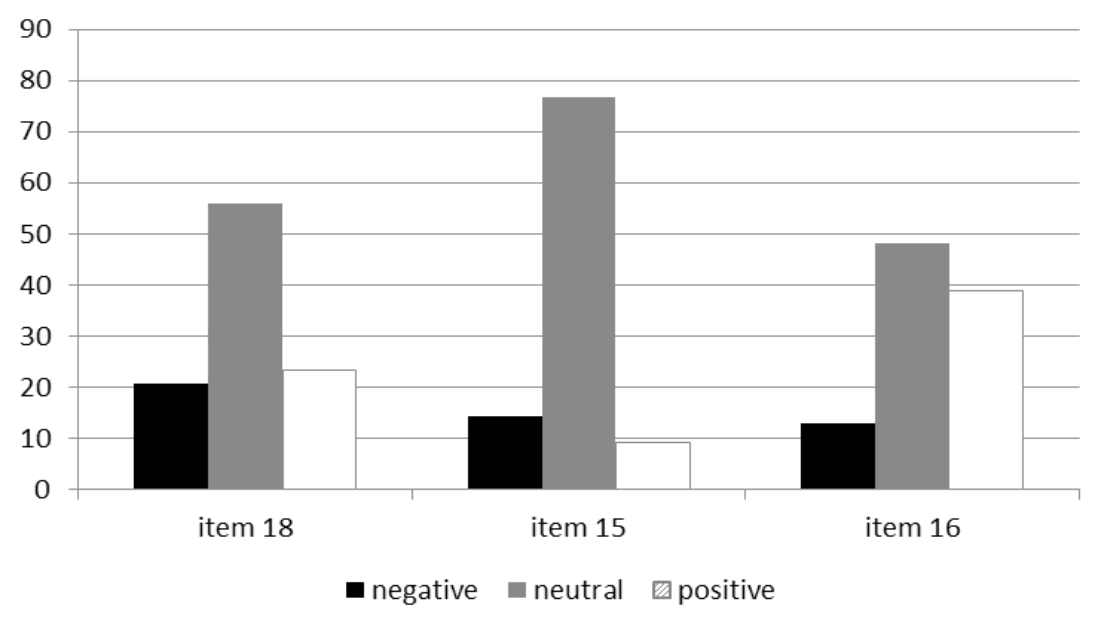

Figure 2. Evaluation of one's capabilities - responses with the most negative evaluation.

On the contrary, the item with the most negative evaluation was promotion of mathematics during extra-curricular activities (Item 18), followed by appreciation of teaching by school management or teachers (Item 15), and ability to answer students' questions (Item 16). It needs to be stated however that these three items with negative evaluation also had the highest number of neutral responses (Figure 2).

Figure 3 clearly shows data dispersion, which characterizes data fluctuation around the arithmetic mean. Greater and more frequent deviations from the arithmetic mean suggest greater data dispersion. In this case, greater data dispersion suggests that the respondents significantly differ in their evaluation; smaller data dispersion suggests similar evaluation.

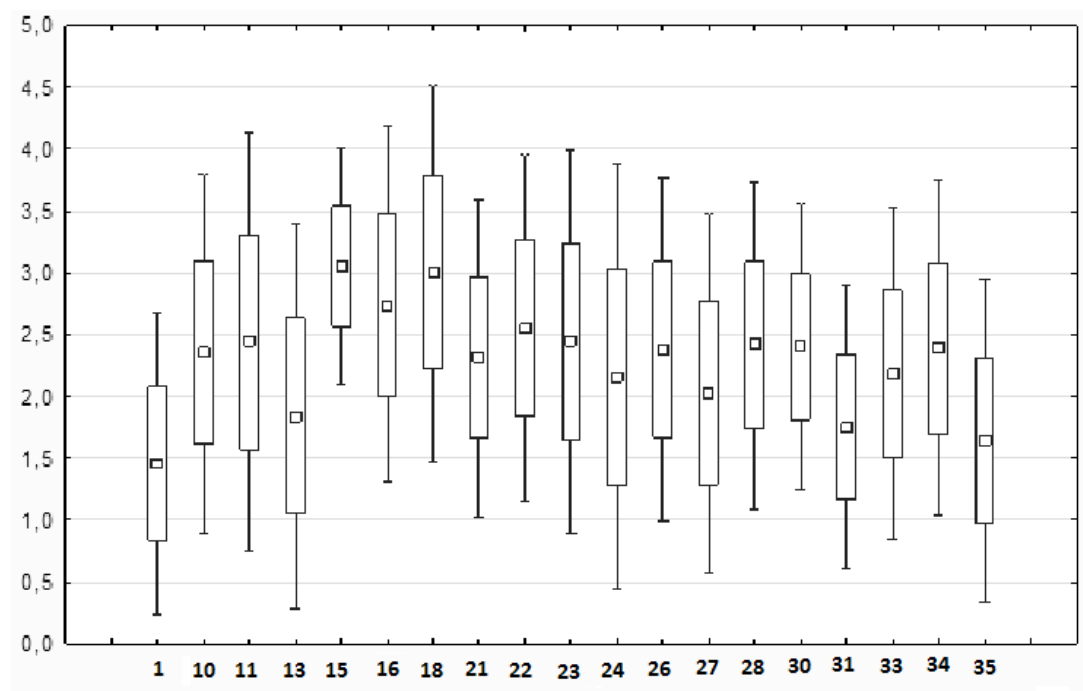

Figure 3. Evaluation of one's capabilities. 
The greatest differences concerned the respondents' beliefs in their ability to provide their students with a feeling of success in mathematics (Item 24), in the evaluation of making their mathematics lessons accessible (Item 11), and in their willingness to respond to their students' questions (Item 13). On the contrary, the greatest agreement was observed in the respondents' opinions about appreciation of teaching by school management and parents (Item 15), in building students' trust in their own capabilities (Item 31), and in the ability to develop students' mathematical thinking (Item 30).

In Item 30 the respondents selected only between positive (54.55\%) and neutral responses (45.45\%). This means that the respondents were either ready to explain complex mathematical concepts to their students in a clear way, or had an undecided attitude, but in no way negative.

\section{Different Evaluations}

In the analysis of the differences in the responses of prospective teachers between the ESTP and ESSETP groups, a statistically significant difference was observed only in two items. The first item concerned the evaluation of the respondents' ability to clearly explain complex mathematical relations (Item 22), which apparently differed between the two groups (Figure 4). $57.14 \%$ of students in the ESTP group indicated a positive evaluation, $36.74 \%$ a neutral evaluation, and $6.12 \%$ a negative evaluation. $28.57 \%$ of prospective teachers in the ESSETP group indicated a positive evaluation, $60.71 \%$ a neutral evaluation, and $10.72 \%$ a negative evaluation.

The $p$-value of this item was .04882, which was lower than the determined level of significance and therefore the null hypothesis was rejected (there is a statistically significant difference between the responses). The respondents in the ESTP group felt much better prepared for explaining complex mathematical relations in a concise and clear manner compared with the respondents in the ESSETP group.

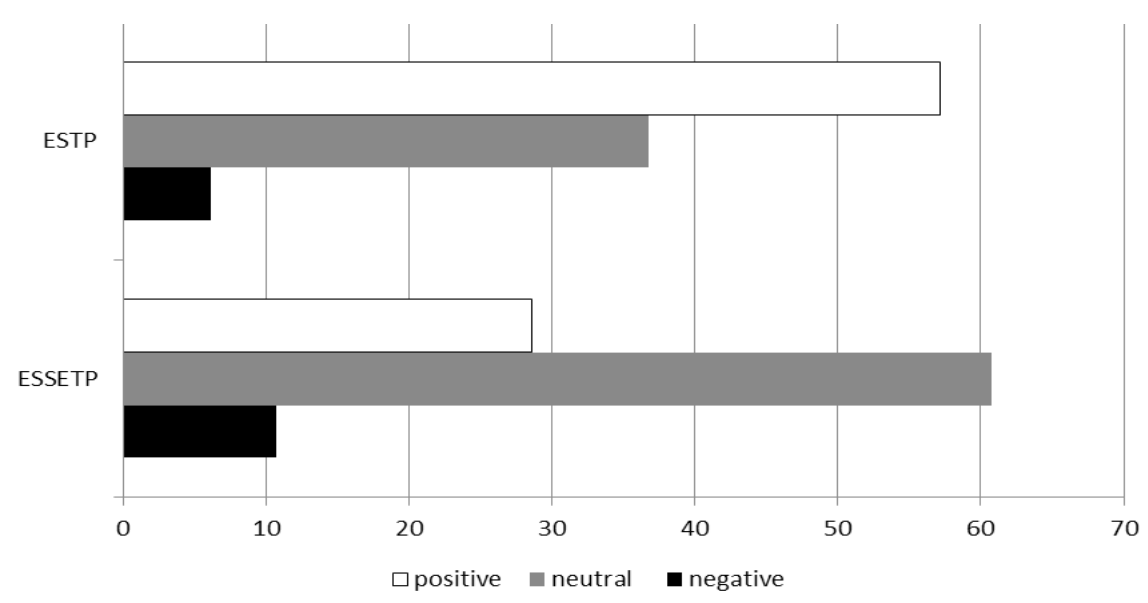

Figure 4. Ability to explain complex mathematical relations.

The other item with differences in evaluation examined prospective teachers' ability to provide a feeling of success for all learners in mathematics (Item 24). The respondents in the ESTP group indicated $57.14 \%$ of positive, $37.70 \%$ of neutral and $8.16 \%$ of negative responses. The respondents in the ESSETP group indicated $85.71 \%$ of positive, $14.29 \%$ of neutral and no negative responses (Figure 5).

\begin{tabular}{l} 
PROBLEMS \\
OF EDUCATION \\
IN THE 21 $1^{\text {st }}$ CENTURY \\
Vol. 77, No. 1, 2019 \\
\hline 249
\end{tabular}


PROBLEMS

OF EDUCATION

IN THE $21^{\text {st }}$ CENTURY

Vol. 77, No. 1, 2019

250

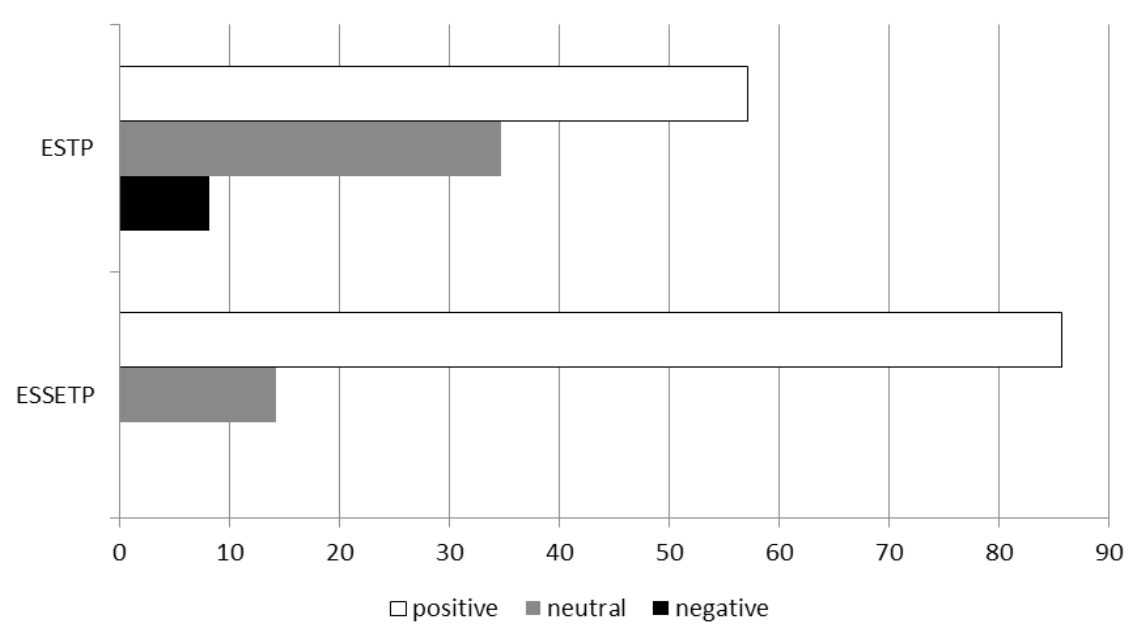

Figure 5. Ability to provide a feeling of success for learners in mathematics.

The test confirmed a statistically significant difference in the responses between the ESTP and ESSETP groups, because the $p$-value was .03638, which is lower than the determined level of significance. An analysis of the proportion of positive responses indicated an odds ratio of .279153. This means that the probability of a positive response is about three times higher in the ESSETP group compared with the ESTP group. As a result, three times more ESTP prospective teachers are convinced that they will be able to provide a feeling of success in mathematics for all learners irrespective of their abilities.

\section{Discussion}

In the research it was observed that students of teacher training courses showed a surprisingly high level of self-efficacy. The results are probably affected by the fact that the students involved in the research had limited experience with practical teaching and had not experienced the everyday load of the teaching profession or the activities that are associated with the school life. A similar result was also concluded by Gavora (2012), who observed relatively high self-efficacy values among students, corresponding to approximately the same level as reported by teachers with experience of up to five years.

Gökmen et al. (2011) observed a difference in the assessment of self-efficacy among pre-service teachers by year of study, which was not confirmed in the present research study. The conclusions by Yavuz et al. (2013), according to whom self-efficacy does not differ by gender, were not confirmed. By contrast, Özdemir (2008) found that women's perception of self-efficacy for classroom management was higher compared with men and suggested two possible explanations. The first is the fact that education is dominated by female teachers; the second is based on an assumption of more appropriate personality qualities in women for the teaching profession.

\section{Conclusions}

The purpose of this paper is to use the SEPTM instrument to investigate the preparation of prospective teachers in the Czech Republic. The analysis clearly supports the conceptualization of prospective teacher self-efficacy as a multidimensional construct. A total of three separate but correlated areas of teacher self-efficacy were identified: evaluation of one's capabilities, quality of one's readiness, and teachers' responsibility for students' performance. 
Overall, it may be concluded that the readiness of prospective teachers for effective teaching was assessed rather positively. Generally, pre-service teachers believe in their own qualities, abilities to use various teaching methods and procedures, and their readiness for improvement in these areas. Most of them consider the personality of the teacher one of the major determinants of effective teaching and working with students.

Prospective teachers feel most prepared in being able to develop and support students' mathematical thinking. It could be speculated that most teachers do not have optimistic views about what they accomplish in math education and that they do not perceive narrow limitations. This statement was not confirmed by the results of the present study because students felt able to develop and enhance students' mathematical thinking. They also think that they are prepared to constantly improve the quality of their mathematics teaching and to teach mathematics in a comprehensible way.

A crucial aspect in overall prospective teachers' self-efficacy in the area of didactic readiness might be their effort to support their students' trust in their mathematical capabilities. Although this point was dominated by positive evaluation, there were also some negative responses. Concerning the nature of the teaching profession, one would expect only positive responses. Even the neutral evaluation is surprising, and the following question emerges: What are the beliefs of a prospective teacher who does not wish to support the learners' confidence in mathematics? Even more worrying is one negative response concerning prospective teachers' effort to make teaching mathematics enjoyable for the learners. Are they planning to exert little effort? What are their ideals and enthusiasm at the beginning of their teaching career?

There was an assumption in the beginning that there were some differences between the groups of students depending on their field of interest. Only two were identified in the present study: the ability to explain complex mathematical relations and the ability to provide a feeling of success for learners in mathematics. Future research should, therefore, focus more on these areas and analyse them in detail.

Several limitations in this study should be pointed out. The sample of prospective teachers was recruited only from one university. Although it was the top sample of students, it may not be representative of the nation. Using the SEPTM instrument in longitudinal studies would be useful. Future research should also examine whether the three dimensions of teacher self-efficacy are related to other constructs (for example math anxiety) and whether they have a different impact on teaching strategies and teacher behaviour.

\section{Acknowledgment}

This article originated within the project Teaching situations in mathematics education (IGA_PdF_2019_007).

\section{References}

Allinder, R. M. (1994). The relationship between efficacy and the instructional practices of special education teachers and consultants. Teacher Education and Special Education, 17, 86 -95.

Ashton, P. (1984). Teacher efficacy: A motivational paradigm for effective teacher education. Journal of Teacher Education, 54, 28-32.

Bandura, A. (1977). Self-efficacy: Toward a unifying theory of behavioral change. Psychological Review, $84,191-215$.

Bandura, A. (1981). Self-referent thought: A developmental analysis of self-efficacy. Social Cognitive Development: Frontiers and Possible Futures, 200(1), 200-239.

Bandura, A. (1997). Self-efficacy: The exercise of control. New York: Freeman.

Bandura, A. (2002). Social foundations of thought and action. In Marks, D. F. (Ed.), The health psychology reader (pp. 94-106). Sage.

\begin{tabular}{l} 
PROBLEMS \\
OF EDUCATION \\
IN THE 21 $1^{\text {st }}$ CENTURY \\
Vol. 77, No. 1, 2019 \\
\hline 251
\end{tabular} 
Radka DOFKOVÁ. Evaluation of self-efficacy in prospective primary school teachers in the context of mathematics teaching PROBLEMS
OF EDUCATION
IN THE $21^{\text {st }}$ CENTURY
Vol. 77, No. 1,2019

252

Bandura, A. (2006a). Adolescent development from an agentic perspective. In F. Pajares, \& T. Urdan (Eds.), Self-efficacy beliefs of adolescents (pp. 1-43). Greenwich, Connecticut: Information Age Publishing.

Bandura, A. (2006b). Guide for constructing self-efficacy scales. In F. Pajares, \& T. Urdan (Eds.), Self-efficacy beliefs of adolescents (pp. 307-337). Greenwich, Connecticut: Information Age Publishing.

Burley, W. W., Hall, B. W., Villeme, M. G., \& Brockmeier, L. L. (1991, April). A path analysis of the mediating role of efficacy in first-year teachers' experiences, reactions, and plans. Paper presented at the annual meeting of the American Educational Research Association, Chicago.

Dofková, R., \& Kvintová, J. (2018). Self-efficacy in pre-service teachers of mathematics - the development of a new testing instrument in the Czech Republic. In L. G. Chova, A. L. Martinez, \& I. C. Torres (Eds.) 11th annual International Conference on Education and New Learning Technologies Conference Proceedings (pp. 3-12). Valencia.

Dofková, R., \& Kvintová, J. (2017). Vnímání vlastni efektivity učiteli̊ primárního vzdělávání: kvalitativni analýza matematické a didaktické připravenosti v pregraduální připravě [The perception of own effectiveness of primary education teachers: Qualitative analysis of mathematics and didactics readiness in pre-graduate preparation]. Olomouc: Univerzita Palackého, 2017.

Chráska, M. (2007). Metody pedagogického výzkumu [Methods of pedagogical research]. Praha: Grada Publishing a.s.

Enochs, L. G., \& Riggs, I. M. (1990). Further development of an elementary science teaching efficacy belief instrument: A preservice elementary scale. School Science and Mathematics, 90(8), 694706.

Fuchs, L. S., Fuchs, D., \& Bishop, N. (1992). Instructional adaptation for students at risk. Journal of Educational Research, 86, 70-84.

Gavora, P. (2010). Slovak pre-service teacher self-efficacy: Theoretical and research considerations. The New Educational Review, 21(2), 17-30.

Gavora, P. (2012). Skúsenosti so zist'ovaním self-efficacy učitela pomocou dotazníka OSTEN [Experiences with measuring teacher self-efficacy with OSTES]. In V. Ježková (Ed.), Kvalita ve vzdělávání (pp. 9-11). Praha: Pedagogická fakulta UK.

Gibson, S., \& Dembo, M. H. (1984). Teacher efficacy: A construct validation. Journal of Educational Psychology, 76(4), 569.

Glickman, C. D., \& Tamashiro, R. T. (1982). A comparison of first-year, fifth-year, and former teachers on efficacy, ego-development, and problem-solving. Psychology in the Schools, 19, 558-62.

Gökmen, A., et al. (2011). An investigation into candidate biology teachers' self-efficacy beliefs related to the teaching process. Social and Behavioral Sciences, 15, 2559-2563.

Guskey, T. R. (1988). Teacher efficacy, self-concept, and attitudes toward the implementation of instructional innovation. Teaching and Teacher Education, 4, 63-69.

Guskey, T. R., \& Passaro, P. D. (1994). Teacher efficacy: A study of construct dimensions. American Educational Research Journal, 31(3), 627-643.

Housego, B. E. J. (1992). Monitoring student teachers' feelings of preparedness to teach, personal teaching efficacy, and teaching efficacy in a new secondary teacher education program. Alberta Journal of Educational Research, 38(1), 49-64.

Hoy, W. K., Tarter, C. J., \& Hoy, A. W. (2006). Academic optimism of schools: A force for student achievement. American Educational Research Journal, 43(3), 425-446.

Meijer, C. J. W., \& Foster, S. F. (1988). The effect of teacher self-efficacy on referral change. Journal of Special Education, 22, 378-385.

Muijs, D., \& Reynolds, D. (2002). Teacher beliefs and behaviors: What matters. Journal of Classroom Interaction, 37, 3-15.

Özdemir, S. M. (2008). An investigation of prospective primary teachers' self-efficacy beliefs regarding teaching process in terms of certain variables. Educational Administration: Theory and Practice, 54, 277-306.

Pajares, F. (1997). Current directions in self-efficacy research. In H. W. Marsh, R. G. Craven, \& D. M. McInerney (Eds.), International advances in self research (pp. 1-49). Greenwich, Connecticut: Information Age Publishing. 
Schunk, D. H., \& Meece, J. L. (2006). Self-efficacy development in adolescence. In F. Pajares, \& T. Urdan (Eds.), Self-efficacy beliefs of adolescents (pp. 71-96). Greenwich, Connecticut: Information Age Publishing.

Skaalvik, E. M., \& Skaalvik, S. (2007). Dimensions of teacher self-efficacy and relations with strain factors, perceived collective teacher efficacy, and teacher burnout. Journal of Educational Psychology, 99(3), 611.

Skaalvik, E. M., \& Skaalvik, S. (2010). Teacher self-efficacy and teacher burnout: A study of relations. Teaching and Teacher Education, 26(4), 1059-1069.

Soodak, L. C., \& Podell, D. M. (1996). Teacher efficacy: Toward the understanding of a multi-faceted construct. Teaching and Teacher Education, 12, 401-411.

Team, R. C. (2013). R: A language and environment for statistical computing. R Foundation for Statistical Computing. Vienna, Austria. Retrieved from https://www.r-project.org/.

Yavuz, G., et al. (2013). Self-efficacy beliefs of prospective primary mathematics teachers about mathematical literacy. Journal of College Teaching \& Learning, 10(4), 279-288.

Watters, J. J., \& Ginns, I. S. (1995). Origins of, and changes in preservice teachers'science teaching selfefficacy. Presented at the annual meeting of national association for research in science Teaching, April 22-25, 1995, San Francisco CA.

Woolfolk, A. E., \& Hoy, W. K. (1990). Prospective teachers' sense of efficacy and beliefs about control. Journal of Educational Psychology, 82(1), 1-81.

Received: February 12, 2019

Accepted: April 02, 2019

Radka Dofková

Ph.D, Assistant Professor, Department of Mathematics, Faculty of Education, Palacky University Olomouc, Žižkovo nám. 5, 77140 Olomouc, Czech Republic.

E-mail: radka.dofkova@upol.cz 